\title{
Penetapan Kadar Vitamin B1 Pada Genjer (Limnocharis flava) Dengan Pengukusan Menggunakan Spektrofotometer UV-VIS
}

\author{
Previta Zeisar Rahmawati ${ }^{1}$, Dewi Cholimatus Sa'diyah ${ }^{2}$ \\ ${ }^{1,2)}$ Prodi D3 TLM STIKes Maharani Malang \\ Correspondence to: previta.zr@gmail.com
}

Tanggal Submit: 5 Mei 2020

Tanggal Review:

5 Oktober 2020

Tanggal Publish

Online:

10 Desember 2020

\begin{abstract}
Genjer (Limnocharis flava) is a daily consumable plant that often used as vegetable by wide society. It known have completed nutritional content such as protein, carbohydrate, mineral and vitamin. Genjer also known as good source of B1 vitamin. The purpose of this study was to identify B1 vitamin level of fresh and steamed genjer plant. Genjer plant were steamed for 2 minutes and 4 minutes. We also want to examine the best steamed time for the plant towards B1 vitamin level. Determination of genjer B1 vitamin level wa used UV-Vis Spectrofotometry at $511 \mathrm{~nm}$, and thiamine was used as the standart solution. The study shown that $\mathrm{B} 1$ vitamin level were $\mathrm{o}, 121 \mathrm{mg} / 100 \mathrm{~g}, 0,035 \mathrm{mg} / 100 \mathrm{~g}$ and $0,027 \mathrm{mg} / 100 \mathrm{~g}$ in fresh, 2 minutes steamed and 4 minutes steamed genjer plants respectively. We were done a quantitatively analysis of collected data to describe B1 vitamin level in treated genjer plants. The result showed that the longer of steamed period will reduce more of $\mathrm{B} 1$ vitamin level at genjer plants. We suggested that B1 vitamin more soluble in water and processing technique related with water have an effect towards B1 vitamin level, and 2 minutes steaming reduce less of B1 Vitamin compared to 4 minutes steaming.
\end{abstract}

Keywords: Genjer (limnocharis flava), Analysis of Vitamin B1 Levels, UV-Vis Spectrophotometer

\section{PENDAHULUAN}

Genjer (Limnocharis flava)

yang juga bisa disebut dengan istilah yellow velvetleaf atau sawah-lettuce, merupakan tanaman liar yang terdapat di area persawahan, sungai atau rawarawa. Sebagian besar masyarakat beranggapan tanaman genjer dianggap sebagai gulma karena sifatnya yang tumbuh liar dan sangat mengganggu jika genjer tersebut tumbuh di daerah persawahan. Akan tetapi genjer memiliki beberapa manfaat, yaitu dapat digunakan sebagai bahan dalam proses penyerapan logam berat yang terdapat pada tanah, sebagai fitoremediasi yang dapat menurunkan nilai BOD dalam limbah (Thuraidah, dkk 2016) dan dapat juga digunakan sebagai obat karena genjer memiliki banyak 
kandungan nutrisi (Chaidir dkk., 2016).

karena tanaman genjer juga memiliki kelebihan dengan banyaknya kandungan gizi di dalamnya, genjer dapat digolongkan sebagai sayuran. Tanaman genjer dikonsumsi oleh sebagian besar masyarakat Indonesia sebagai sayuran pendamping yang dikonsumsi sehari-hari.

Tanaman genjer memiliki kandungan gizi dan nutrisi makanan yang cukup lengkap, seperti karbohidrat, protein, mineral, dan vitamin. Sumber vitamin yang terkandung dalam genjer adalah vitamin B1 (Tiamin). Angka kebutuhan tiamin pada orang dewasa berkisar antara 0,7-1,1 mg perhari (AKG, 2013). Bentuk murni dari vitamin B1 adalah Tiamin hidroklorida, yang merupakan vitamin larut air. Vitamin B1 memiliki peran penting dalam metabolisme lipida dan karbohidrat yaitu untuk pembentukan energi serta produksi neurotransmitter. Pada makanan, tiamin ditemukan dalam bentuk senyawa kompleks yaitu kompleks proteinfosfat. (Fauziah dkk., 2016).

Fungsi utama tiamin yaitu untuk mengatasi gangguan saraf otot seperti nyeri dan rematik, serta dapat mengobati seseorang yang mengalami defisiensi vitamin B1 seperti penyakit beri - beri, tubuh lelah, palpitasi (jantung berdebar) dan juga dapat mengatasi ganguan metabolik.

Defisiensi Vitamin B1 menyebabkan berbagai macam gejala kardiovaskular dan gejala neurologis (Fauziah dkk., 2016). Tiamin tidak tersimpan dalam tubuh dan jika terdapat kelebihan tiamin dalam tubuh maka akan segera dikeluarkan melalui urin. Oleh karena itu, sangat penting menjaga kebutuhan akan vitamin B1 dalam tubuh, salah satu cara yaitu dengan mengkonsumsi berbagai sumber makanan yang mengandung tiamin. Tiamin memiliki ciri yaitu mudah terurai pada suhu tinggi. Oleh karena itu, dalam proses pengolahan genjer perlu diperhatikan agar kandungan tiamin tidak banyak yang terurai (Lean, 2013).

Selain itu karakteristik tiamin yaitu merupakan senyawa yang memiliki sifat kurang stabil. Stabilitas tiamin dapat dipengaruhi oleh suhu, $\mathrm{pH}$ dan juga cara pengolahan. Faktor penting yang berpengaruh terhadap kadar tiamin dan hilangnya kandungan tiamin dalam sayuran/bahan pangan adalah pada saat proses pencucian (Fauziah, dkk., 2016). Tanaman genjer yang akan dimasak terlebih dahulu pada umumnya dilakukan proses pencucian, proses pencucian dapat menyebabkan turunnya kandungan vitamin B1 yang mana vitamin B1 memiliki sifat mudah larut dalam air (Lean, 2013). 


\section{Dalam pengolahan bahan METODE PENELITIAN}

pangan dengan menggunakan suhu tinggi, cahaya, dan oksigen dapat menyebabkan hilangnya sebagian besar zat gizi terhadap makanan tersebut. Salah satu proses pemasakan dan pengolahan genjer yang paling sering dilakukan adalah pengukusan. Pengolahan genjer dengan cara dikukus memiliki keunggulan yaitu dapat meminimalkan penurunan kandungan zat gizi pada genjer. Sedangkan bila pengolahan dan pemasakan genjer dilakukan dengan cara perebusan dan penumisan kadar zat gizi dalam genjer cenderung lebih banyak menurun. Besarnya penurunan kadar zat gizi makanan pada proses pengkukusan bergantung dari cara mengukus dan jenis makanan yang dikukus (Lean, 2013).

Penelitian ini memiliki tujuan yaitu untuk mengetahui dan mengidentifikasi kadar vitamin B1 pada tanaman genjer segar dan pada tanaman genjer yang telah dilakukan proses pengukusan selama 2 menit dan 4 menit serta menentukan waktu pengukusan terbaik untuk pengolahan genjer. Pengukuran kadar vitamin B1 pada penelitian ini dilakukan dengan Spektofotometri UV-Vis dengan larutan standar tiamin pada panjang gelombang daerah visibel.

\section{Alat dan Bahan}

Alat-alat yang digunakan adalah spektrofotometri UV-Vis (Shimadzu UV-1700), Timbangan analitik, erlenmeyer, pengaduk, pipet tetes, labu ukur, corong, gelas ukur, gelas beker, blender, kertas saring wahtman, kaca arloji, tisue, spatel.

Bahan-bahan yang digunakan yaitu, tanaman genjer yang diambil di persawahan Desa Tegalgondo, Kecamatan Karangploso Kota Malang, standar Tiamin, akuades, polivinil alkohol, larutan buffer amonia, indikator bromtimol biru $0,05 \%$

\section{Preparasi Sampel Genjer}

Sampel tanaman Genjer segar dipotong menjadi ukuran yang kecilkecil dengan menggunakan pisau, kemudian dicuci menggunakan air bersih, dan ditiriskan. Ditimbang masing-masing 100 gram daun dan batang genjer untuk sampel eksperimen dan sampel kontrol. Kemudian dilakukan pengukusan genjer pada bagian daun dan batang selama 2 menit dan 4 menit. Sedangkan pada sampel kontrol tidak di lakukan proses pengukusan.

Sampel genjer ditimbang masing-masing 10 gram genjer segar sebagai kontrol, genjer kukus 2 menit, dan genjer kukus 4 menit. Kemudian diblender untuk mendapatkan ekstrak 
kasar genjer. Saring ekstrak kasar menggunakan kertas saring untuk mendapatkan filtrat. Kemudian dimasukkan kedalam labu ukur dan ditambahkan akuades hingga tanda batas dan diamkan pada suhu ruang \pm 1 jam.

Penetapan kadar vitamin B1 dengan Spektrofotometer UV-Vis

1. Penentuan panjang gelombang maksimal tiamin

Penentuan $\lambda$ maks dari tiamin diperoleh dengan cara mengukur nilai absorbansi larutan standar tiamin pada $\lambda 400-700 \mathrm{~nm}$. Standar tiamin dibuat konsentrasi larutan stok tiamin standar pada konsentrasi $80 \mathrm{ppm}$ dengan cara memipet $4 \mathrm{ml}$ larutan standar, dimasukan pada labu ukur $25 \mathrm{ml}$. Ditambahkan dengan larutan buffer ammonia $1,5 \mathrm{ml}$ dan $0,05 \%$ indikator bromtimol biru sebanyak 3 ml. Kemudian ditambahkan $1 \mathrm{ml}$ polivinil alkohol konsentrasi $1 \%$, dan tambahkan aquades hingga batas garis meniskus, kemudian dihomogenkan. $\lambda$ maks diukur dengan panjang gelombang 230 $850 \quad \mathrm{~nm}$ menggunakan spektrofotometer UV-Vis.

2. Penentuan kadar standar tiamin

Ditimbang vitamin B1 sebanyak $25 \mathrm{mg}$ menggunakan timbangan analitik. Di masukkan dalam labu ukur $50 \mathrm{ml}$ dan ditambahkan aquades hingga batas garis meniskus, sehingga didapatkan larutan standar tiamin dengan konsentrasi 500 ppm.

Pembuatan kurva standar tiamin dengan mengukur larutan standar konsentrasi 4, 8, 12, 16, 20, dan 24 ppm yaitu dengan cara pipet larutan stok dengan konsentrasi 80 ppm diambil sebanyak masingmasing 0,$5 ; 1 ; 1,5 ; 2 ; 2,5$; dan $3 \mathrm{ml}$, masukkan pada labu ukur $10 \mathrm{ml}$. Tambahkan 1,5 ml larutan buffer ammonia, $3 \mathrm{~mL}$ indikator bromotimol biru $0,05 \%$ dan $1 \mathrm{ml}$ polivinil alkohol 1\%. Tambahkan aquades hingga batas garis meniskus, homogenkan. Kemudian ukur serapan pada panjang gelombang $511 \mathrm{~nm}$.

3. Penentuan kadar vitamin B1 pada genjer

Penentuan kadar vitamn B1 pada genjer dilakukan dengan cara $5 \mathrm{ml}$ fitrat sampel genjer kemudian dimasukkan pada labu ukur 25 ml. Ditambahkan 1,5 ml larutan buffer ammonia dan $3 \mathrm{ml}$ indikator bromtimol biru 0,05\%. Kemudian tambahkan $1 \mathrm{ml}$ polivinil alkohol 1 $\%$, tambahkan aquades hingga batas garis meniskus, kemudian dihomogenkan. Ukur serapan sampel pada $\lambda$ maks $511 \mathrm{~nm}$ dengan melihat nilai absorbansi 
pada spektrofotometer UV-Vis.

Hitung kadar vitamin B1 dapat

dihitung dengan rumus:

$$
\mathrm{Cs}=\frac{\mathrm{C} / 1000 \times \mathrm{V}}{\mathrm{W}}
$$

Keterangan:

Cs : Kadar vitamin B1 (mg/100 g)

$\mathrm{C}$ : Konsentrasi hasil pengukuran

(x)

$\mathrm{V}$ : Volume filtrat

W : Berat sampel

1000 : konversi dari ppm ke mg/g

\section{HASIL}

Pengukuran kadar vitamin B1 terhadap tanaman genjer dengan menggunakan spektrofotometri UV-VIS sebelumnya ditentukan panjang gelombang maksimal dari standar tiamin. Hasil pengukuran panjang gelombang maksimum tiamin pada rentang spektrum $230-850 \mathrm{~nm}$ adalah memiliki panjang gelombang maksimum yaitu $511 \mathrm{~nm}$ dengan absorbansi maksimum dengan nilai 0,029

$\begin{array}{rrr}\text { Pengukuran } & \text { kurva standar } \\ \text { dilakukan dengan } & \text { cara }\end{array}$
melarutkan larutan stok tiamin kedalam beberapa konsentrasi yaitu 4, 8, 12, 16, 20, dan 24 ppm. Hasil pengukurannya adalah sebagai berikut :
TABEL 1. Absorbansi larutan standar Vitamin B1

\begin{tabular}{|c|c|}
\hline $\begin{array}{c}\text { Konsentrasi larutan } \\
\text { standar tiamin (ppm) }\end{array}$ & Absorbansi (A) \\
\hline 4 & 0,081 \\
\hline 8 & 0,175 \\
\hline 12 & 0,259 \\
\hline 16 & 0,368 \\
\hline 20 & 0,454 \\
\hline 24 & 0,587 \\
\hline
\end{tabular}

Dari konsentrasi larutan standar

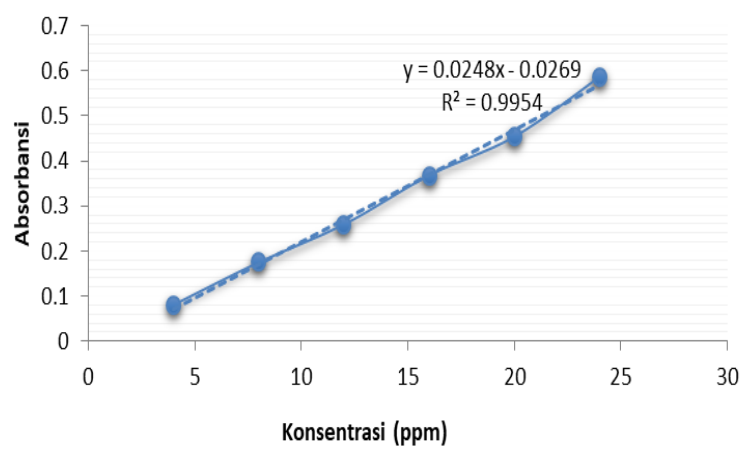

tiamin tersebut dibuat kurva larutan standar tiamin (Vitamin B1) dengan sumbu X sebagai konsentrasi larutan standar tiamin dan sumbu $\mathrm{Y}$ adalah absorbansi larutan standar tiamin.

GAMBAR 1. Kurva standar vitamin B1 (Tiamin)

Kurva standar vitamin B1 diperoleh dari hasil persamaan garis linier $y=0,0248 x-0,0269$ dengan nilai koefisien determinasi $\left(\mathrm{R}^{2}\right)$ yaitu 0,9954 . Nilai tersebut menunjukan adanya linearitas yang menyatakan terdapat hubungan antara konsentrasi (pada sumbu $X$ ) dengan absorbansi (pada sumbu Y). Hal tersebut berarti bahwa persamaan garis $\mathrm{y}=0,0248 \mathrm{x}-0,0269$ dapat digunakan untuk menentukan kadar tiamin pada sampel. 
Hasil pengukuran kadar vitamin

B1 pada genjer (Limnocharis Flava) melalui pengukusan dengan menggunakan spektrofotometer UV-Vis didapatkan data sebagai berikut dengan hasil pengukuran kadar pada genjer segar yang digunakan sebagai kontrol diperlihatkan pada tabel 2:

TABEL 2. Hasil Analisa Kadar Vitamin B1 Pada Genjer

\begin{tabular}{|c|c|c|c|}
\hline Sampel & $\begin{array}{c}\text { Absorbansi } \\
\text { rata-rata } \\
\left(\sum \mathbf{A}\right)\end{array}$ & $\begin{array}{c}\text { Kadar } \\
\text { Vitamin } \\
\mathbf{B 1} \\
(\mathbf{m g} / \mathbf{1 0 0} \\
\mathbf{g})\end{array}$ & $\begin{array}{c}\text { \% } \\
\text { Penurunan } \\
\text { Kadar } \\
\text { Vitamin } \\
\text { B1 }\end{array}$ \\
\hline G0 & 0,578 & 0,121 & - \\
\hline G2 & 0,147 & 0,035 & $71,1 \%$ \\
\hline G4 & 0,111 & 0,027 & $77,7 \%$ \\
\hline \multicolumn{3}{|c|}{ Keterangan : } \\
G0: Genjer Segar \\
G2: Genjer Kukus (2 menit) \\
G4: Genjer Kukus (4 menit)
\end{tabular}

Pada gambar 2, diperlihatkan bahwa semakin lama waktu pengukusan, akan semakin menurun kadar vitamin B1 yang terkandung dalam genjer. Banyaknya penurunan kadar vitamin B1 setelah pengukusan dapat dilihat pada gambar berikut:

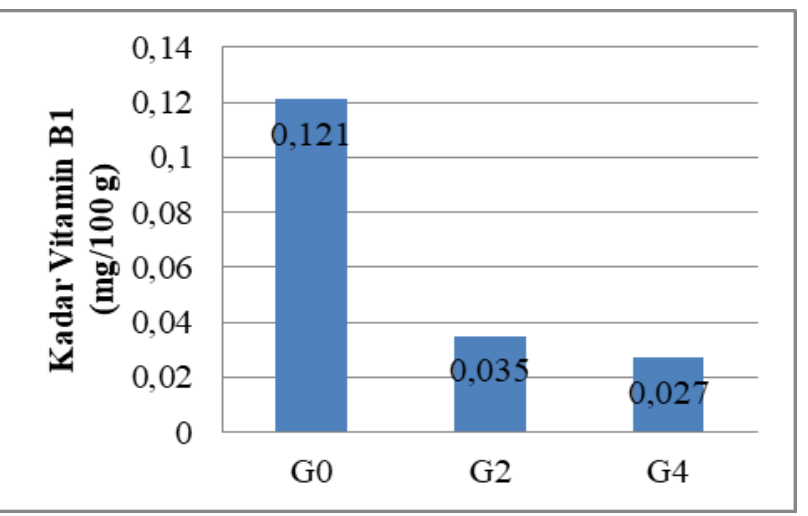

\section{PEMBAHASAN}

Pengukuran kadar vitamin B1 terhadap tanaman genjer dengan menggunakan spektrofotometri UV-VIS sebelumnya ditentukan panjang gelombang maksimal dari standar tiamin. Hasil pengukuran panjang gelombang maksimum tiamin pada rentang spektrum 230 - $850 \mathrm{~nm}$ adalah memiliki panjang gelombang maksimum yaitu $511 \mathrm{~nm}$ dengan absorbansi maksimum dengan nilai 0,029. Tujuan dari penentuan panjang gelombang maksimum tiamin adalah untuk mendapatkan nilai absorbsivitas sehingga memberikan sensitivitas pengukuran tertinggi. Berdasarkan penelitian yang telah dilakukan hasil pengukuran penentuan panjang gelombang maksimum vitamin B1 dapat ditunjukkan pada Gambar 1, nilai absorbansi maksimum dari larutan standar tiamin diperoleh panjang gelombang maksimal dengan nilai 511 nm. Nilai $\lambda$ maks $511 \mathrm{~nm}$ memiliki pengertian panjang gelombang tersebut adalah panjang gelombang dari warna komplementer pada larutan standar tiamin yang telah diukur. $\lambda$ maks 511 $\mathrm{nm}$ digunakan untuk pengukuran selanjutnya. Beberapa literatur menyebutkan bahwa vitamin B1 akan memberikan absorbansi maksimal pada $\lambda 423$ nm (Fauziah dkk, 2016), 515 nm 
(Lestariana dan madiyan, 1998), dan 520 nm (Indrasari, 2011).

Penentuan kadar vitamin B1 pada tanaman genjer dilakukan proses analisis tidak hanya pada bagian daun saja tetapi juga batang, karena pada dasarnya masyarakat mengkonsumsi genjer tidak hanya bagian daunnya saja tetapi juga bagian batang. Preparasi sampel genjer pada genjer segar dengan cara penghomogenan sampel dengan cara dihaluskan menggunakan blender yang kemudian diambil filtratnya dan dimasukkan dalam labu ukur $100 \mathrm{~mL}$. Sedangkan untuk sampel genjer yang di kukus, dengan perlakuan sama tetapi dilakukan pengukusan dahulu selama 2 menit dan 4 menit sebelum sampel dihaluskan dengan blender. Pada sampel genjer yang dikukus, pemilihan waktu pengkukusan berdasarkan optimasi waktu peneliti yang dilakukan sebelumnya dalam studi pendahuluan berdasarkan tekstur dari genjer setelah di kukus mulai dari menit ke 1 sampai menit ke 5.

Pada penelitian ini kadar vitamin B1 pada genjer segar didapatkan sebesar 0,121 mg/100 g, kadar vitamin B1 yang didapat ini berbeda dengan kadar vitamin B1 yang disebutkan oleh Depkes (1992) yang menyatakan kandungan vitamin B1 pada genjer adalah $0,07 \mathrm{mg} / 100 \mathrm{~g}$. Perbedaan kadar vitamin B1 ini dikarenakan masing- masing vitamin memiliki karakteristik sifat dan kepekaan/sensitifitas yang berbeda-beda terutama terhadap faktor lingkungan seperti $\mathrm{O}_{2}, \mathrm{pH}$, temperatur dan cahaya. Vitamin B1 sendiri merupakan salah satu vitamin yang mudah sekali rusak oleh $\mathrm{pH}$, oksigen, dan panas. Beberapa hal yang bisa dilakukan dalam rangka meminimalkan kerusakan vitamin B1 dalam bahan pangan pada selama proses penanganan, maka penting untuk mempertimbangkan beberapa faktor lingkungan yang telah disebutkan. Dimana termasuk di dalamnya yaitu cara penyimpanan bahan pangan baik untuk sayur segar, buah maupun bahan pangan hasil olahan. Menurut peneliti, perbedaan kadar vitamin B1 pada genjer segar yang telah peneliti ukur dengan literatur yang ada disebabkan oleh faktor-faktor lingkungan genjer yang berbeda dan memungkinkan terjadinya perubahan ataupun kerusakan vitamin B1 pada genjer.

Sedangkan berdasarkan tabel 2 kadar vitamin B1 genjer pada pengukusan 2 menit adalah 0,035 $\mathrm{mg} / 100 \mathrm{~g}$ dengan penurunan $71,1 \%$, dan pada pengukusan 4 menit adalah 0,027 $\mathrm{mg} / 100 \mathrm{~g}$ dengan penurunan $77,7 \%$. Hal tersebut menunjukkan bahwa semakin lama waktu pengukusan, kadar vitamin B1 pada genjer semakin menurun, dan waktu pengukusan 2 menit lebih baik 
daripada 4 menit karena kadar vitamin B1 yang hilang lebih sedikit. Pada penelitian Fauziah, dkk (2016) dalam menentukan besar kadar vitamin B1 pada kacang kedelai dan tempe, pada kacang kedelai didapatkan kadar vitamin B1 dengan nilai yang lebih besar jika dibandingkan dengan vitamin B1 yang ada pada tempe. Hasil tersebut dikarenakan pada saat proses pengolahan kacang kedelai menjadi tempe sebelumnya dilakukan proses pengolahan yang panjang, mulai dari proses pencucian, perendaman hingga proses perebusan, dimana setiap proses tahapan tersebut dapat mempengaruhi kadar vitamin B1. Pada penelitian Indrasari (2011) yang menyatakan bahwa pemasakan beras merah dan putih menjadi nasi mengakibatkan penurunan kadar vitamin B1, B2, B3, dan B6. Dari hasil penelitian tersebut mendukung hasil penelitian ini yang menunjukkan bahwa pengukusan genjer mengakibatkan penurunan kadar vitamin B1. Kadar vitamin B1 pada genjer mengalami kerusakan saat pengukusan dan akan semakin hilang seiring lamanya waktu yang digunakan. Hal ini disebabkan karena sifat vitamin B1 yang mudah terlarut dalam air dan rentan terhadap suhu tinggi saat proses pemanasan yang terlalu lama.
Proses pengukusan (steaming) pada bahan pangan dapat menurunkan kandungan nutrisi. Selain itu jenis bahan pangan yang dikukus juga berpengaruh terhadap nilai kandungan nutrisi yang terdapat dalam bahan pangan tersebut. Kandungan kimia dan vitamin pada sayuran yang telah dilakukan proses pengolahan bertahap, menunjukkan hasil yang lebih rendah jika dibandingkan dengan sayuran yang masih dalam keadaan segar (Azizah, et al., 2009). Seperti pada beberapa penelitiaan sebelumnya, pada penelitian Hok, et al., (2007) yang meneliti pengaruh suhu dan waktu pemanasan terhadap kandungan vitamin A dan C pada tomat, Sejati (2012) meneliti tentang perubahan vitamin C pada pengukusan genjer (limnocharis flava), juga penelitian yang dilakukan oleh Aulia, et al., (2017) tentang pengaruh pengukusan terhadap kadar vitamin $\mathrm{C}$ pada beberapa sayuran hijau. Hasil penelitian-penelitian tersebut juga menunjukkan kecenderungan penurunan kadar vitamin setelah pengukusan, dan akan semakin besar penurunannya pada waktu pengukusan yang lebih lama. Secara umum, pemasakan lebih banyak menurunkan kandungan vitamin sayuran. 


\section{SIMPULAN}

Dari penelitian ini dapat disimpulkan bahwa kadar vitamin B1 pada tanaman genjer (Limnocharis flava) segar memiliki nilai yang lebih tinggi dari nilai standar. Kadar vitamin B1 pada Genjer yang dilakukan pengukusan mengalami penurunan sejalan dengan lama/durasi waktu proses pengukusan.

Saran dalam penelitian ini yaitu perlu dilakukan penelitian lebih lanjut dengan memperhatikan variasi dan kestabilan suhu yang digunakan saat pengukusan agar hasil yang didapat lebih akurat. Selain itu perlu dilakukan uji terhadap potensi anti oksidan pada tanaman genjer

\section{DAFTAR PUSTAKA}

Aulia, Surya. H. (2017). Pengaruh Metode Pemasakan Terhadap Mutu Sayuran Berdaun Hijau. Skripsi. Padang: Fakultas Teknologi Pertanian Universitas Andalas Padang

Azizah, AH; Wee KC; Azizah O; Azizah M. (2009). Effect Of Boiling And Stir Frying On Total Phenolics, Carotenoids And Radical Scavenging Activity Of Pumpkin (Cucurbita moschato). International Food Research Journal 16: 45-51

Bloch, Daniel R. (2014). Menyingkap Tabir Kimia Organik: Panduan Belajar Mandiri. Jakarta: EGC
Chaidir, L. Yuliani, K. Dan Qurrohman, B.F.T., (2016), Eksplorasi dan Karakterisasi Tanaman Genjer (Limnocharis flava (L) Buch) di Kabupaten Pangandaran Berdasarkan Karakter Morfologi dan Agronomi, Jurnal Agro Vol. III, No. 2

Direktorat Gizi Departemen Kesehatan Republik Indonesia. (1992). Kandungan Gizi Genjer. http://www.depkes.go.id

Fauziah, Fitra; Roslinda Rasyid; Angga Prawina Akbar. (2016). Penetapan Kadar Vitamin B1 Pada Kacang Kedelai dan Tempe Yang Beredar Di Pasar Raya Padang Secara Spektrofotometri Visible. Padang: Jurnal Farmasi Higea VIII(1)

Hok, Kang Tuan; Wiwit Setyo; Wenny Irawaty; Felycia Edi Soetaredjo. (2007). Pengaruh Suhu Dan Waktu Pemanasan Terhadap Kandungan Vitamin A Dan C Pada Proses Pembuatan Pasta Tomat.

Surabaya: Fakultas Teknik Jurusan Teknik Kimia Universitas Katolik Widya Mandala Surabaya

Indrasari, Siti Dewi. (2011). Pengaruh Penyosohan Gabah Dan Pemasakan Terhadap Kandungan Vitamin B Beras Merah. Jawa Barat: Balai Besar Penelitian Tanaman Padi

Jacoeb AM, Abdullah A, Rusydi R. (2010). Karakteristik Mikroskopis dan Komposisi Tanaman Genjer (Limnocharis flava) dari Situ Gede Bogor. Bogor: Jurnal Sumberdaya Perairan IV(2): 1-6

Lean, Michael E.J. (2013). Ilmu Pangan, Gizi \& Kesehatan. Yogyakarta: Pustaka Pelajar 
Lestariana, Wiryatun; Maliyah Madiyan. (1988). Analisa Vitamin Dan Elektrolit Organik. Yogyakarta: UGM-Press

Menteri Kesehatan Republik Indonesia. (2013). Lampiran Peraturan Menteri Kesehatan Republik Indonesia Nomor 75 Tahun 2013 Tentang Angka Kecukupan Gizi Yang Dianjurkan Bagi Bangsa Indonesia.

http://www.AngkaKecukupanGizi (AKG)PDFgizi.depkes.go.id. (diakses pada tanggal 18 Januari 2018)

Nurjanah; Agoes M.J; Roni N; Marisa P; Tri Kalbu A.S. (2014). Perubahan Komposisi Kimia, Aktivitas Antioksidan, Vitamin C dan Mineral Tanaman Genjer (Limnocharis Flava) Akibat Pengukusan. Bogor: Jurnal Inovasi dan Kewirausahaan, Fakultas Perikanan dan Ilmu Kelautan, Institut Pertanian Bogor III(3)

Permatasari, Marisa. (2012). Perubahan Aktivitas Antioksidan Tanaman Genjer (Limnocharis Flava) Akibat Pengukusan. Skripsi. Bogor: Program Sarjana Fakultas Perikanan dan Ilmu Kelautan Institut Pertanian Bogor

Ramdhan, Tezar; Syarifah Aminah. (2014). Pengaruh Pemasakan Terhadap Kandungan Antioksidan Sayuran. Jakarta: Buletin Pertanian Perkotaan, Balai Pengkajian Teknologi Pertanian (BPTP) IV(2)
Rasyid, Roslinda; Anisa Nurul Fitria; Humaira Fadhilah. (2014). Pengaruh Lama Pencucian Terhadap Kadar Vitamin B1 Pada Beras Putih dan Beras Merah Secara Spektrofotometer Visibel. Padang: Jurnal Farmasi Higea VI(2)

Sejati, Tri, Kalbu, Ardininingrum. (2012). Perubahan Komposisi Kimia, Vitamin C, Dan Mineral Pada Pengukusan Genjer (Limnocharis Flava). Skripsi. Bogor: Program Sarjana Fakultas Perikanan dan Ilmu Kelautan Institut Pertanian Bogor

Setiawan, Yodi. (2014). Studi Kandungan Gizi Dan Kalori Nasi Mocaf (Modified Cassava Flour) Pada Beberapa Proses Pemasakan. Bogor: Program Studi Kimia Fakultas Matematika dan Ilmu Pengetahuan Alam Universitas Pakuan

Thuraidah, Anny., Erie Indah Puspita dan Neni Oktiyani. (2016). Pengaruh Genjer (Limnocharis flava) Terhadap Penurunan Biological Oxygen Demand (BOD) Limbah Industri Karet. Medical Laboratory Technology Journal 2 (1), 2016, 6-10

Webster-Gandy, Joan; Anggela Maden; Michelle Holdsworth. (2014). Gizi \& Dietetika, Edisi 2. Jakarta: EGC 